\title{
FAILURE OF PASSIVE TRANSFER OF HOMOGRAFT SENSITIVITY IN MICE BY MEANS OF EXTRACTS OF SENSITISED LYMPHOID CELLS
}

\author{
Judith Warren and G. Gowland \\ Department of Bacteriology, The London Hospital Medical College, London
}

NAJARIAN AND Feldman (1963) and Najarian (1966) reported experiments in which they injected supernatant or sediment from centrifuged samples of sonicated lymphoid cells, from CBA mice pre-sensitised to A-strain antigens, twice daily for 5 days into non-immune CBA mice grafted with A-strain skin $24 \mathrm{hr}$ previously. They claimed that homograft sensitivity was passively transferred by the supernatant fraction, but not by the sediment. Skin grafts from supernatant-treated mice showed more than 90 per cent. epidermal necrosis when biopsied 6 days after grafting. Over a wide range, this effect was shown to be independent of dosage and to be strain-specific. These authors also claimed that the activity of their supernatant fraction was located in a 7S protein component.

Our experiments are an attempt to repeat these potentially important observations with various combinations of mouse strains and, in certain experiments, modifications of the original experimental design.

\section{MATERIALS AND METHODS}

Mice. Male animals of the following inbred strains were used in these experiments: $\mathrm{A}\left(\mathrm{H}-2^{\mathrm{a}}\right), \mathrm{CBA}\left(\mathrm{H}-2^{\mathrm{k}}\right)$ and $\mathrm{C} 3 \mathrm{H}\left(\mathrm{H}-2^{\mathrm{k}}\right)$.

Sensitisation of syngeneic donors. Syngeneic donors of sensitised lymphoid cells were immunised by grafting with allogeneic tail skin followed by the intraperitoneal injection of $25 \times 10^{6}$ allogeneic spleen cells 2 days later. In the first experiment a triangular piece of skin was sutured to a bed prepared in the nuchal region (Najarian and Feldman, 1963). In all other experiments grafts were placed bilaterally in the thoracic region by the technique of Billingham and Medawar (1951). Batches of donors were sensitised in this manner on 5 consecutive days for each experiment.

Preparation of lymphoid cell extracts. Ten days after grafting, each group of donor mice was killed by cervical dislocation and the lymphoid tissue removed. In most experiments, the spleen and the cervical, axillary, brachial, inguinal and mesenteric lymph-nodes were used, but, in one experiment, only those lymph-nodes (the axillary and cervical nodes) draining the skin graft were used.

Suspensions of lymphoid cells were prepared by the method of Billingham and Brent (1959) in Ringer-phosphate solution, $p \mathrm{H} 7 \cdot 4$, with the addition of polyvinyl-pyrrolidone (MW 24,500, Koch-Light Laboratories, Colnbrook, Bucks) to a final concentration of 0.7 per cent.

The cell suspension was sonicated with an MSE magnetostrictive oscillator (operating at $20 \mathrm{kHz}$ per $\mathrm{s}$ with an output of $60 \mathrm{~W}$ ) for $2 \mathrm{~min}$. During sonication, the suspension was cooled in a continuously stirred freezing mixture of melting ice and sodium chloride; the temperature of the sonicated material never exceeded $5^{\circ} \mathrm{C}$.

Received 11 Oct. 1968; accepted 30 Dec. 1968.

J. MED. MICROBIOL.-VOL. 2 (1969) 
Microscopic examination of the sonicated suspension showed that less than 0.25 per cent. of the original cells remained intact, and dye-exclusion tests using nigrosin showed that none of these was viable.

Following sonication, the homogenate was centrifuged at 2500 r.p.m. for $30 \mathrm{~min}$. at $4^{\circ} \mathrm{C}$. The resultant supernatant was decanted from the sediment and each was made up to a volume in millilitres equivalent to the number of recipients for the respective fraction.

In control experiments, lymphoid tissue from unsensitised syngeneic donors was prepared for injection by the same method.

Treatment of recipients. Recipients, syngeneic with the lymphoid cell donors, were grafted with allogeneic tail skin of the same genotype as that used on the donors. A single graft was placed laterally on the thorax, $24 \mathrm{hr}$ before the start of injections.

In all experiments, the recipients were divided into two groups. The first group received twice daily for 5 days intraperitoneal injections of supernatant, and the second group a similar course of injections of sediment. Each injection consisted of the equivalent of half the yield of lymphoid tissue from one mouse in our experience, 1 mouse equivalent $(M E) \bumpeq 250 \times 10^{6}$ cells $\}$. This amount was chosen because Najarian and Feldman (1963) reported it to be a highly effective dose.

Examination of test grafts. Bandages were removed from the mice on the day after the injections were completed, i.e., 6 days after grafting. Five mice were taken from each supernatant-treated and sediment-treated group and killed by cervical dislocation. Their grafts were removed, fixed in neutral formaldehyde-saline and, after processing, $5 \mu \mathrm{m}$ sections were cut at four different levels across the graft. After staining in haematoxylin and eosin, the degree of epithelial survival in the grafts was assessed microscopically.

The grafts on the remaining mice in each group were inspected daily and the percentage epithelial survival was estimated visually each day until all the grafts had been completely rejected.

Cell transfer experiments. In certain experiments, intact viable lymphoid cells were used to transfer homograft sensitivity passively. Cells from donors sensitised 10 days previously with a single lateral skin graft were transferred to syngeneic recipients that had been grafted with allogeneic skin $24 \mathrm{hr}$ previously. These test grafts were examined visually 6 days after the transfer of pre-sensitised cells.

\section{RESULTS}

\section{Observations on skin graft survival times}

Experiment I. In this experiment donor CBA mice were sensitised to A-strain antigens by the method of Najarian and Feldman (1963).

Table I shows the results of transferring fractions of sonicated lymphoid cells from spleen and lymph-nodes into normal syngeneic recipients carrying an A-strain skin graft. The results are expressed as the number of grafts showing 100 per cent. epithelial survival when inspected at various timeintervals. The controls used in this experiment were CBA recipients, into which fractions from unsensitised CBA lymphoid cells had been injected, and also CBA male mice grafted with A-strain skin but receiving no other treatment.

Table I shows that both fractions from sensitised animals failed completely to produce any signs of accelerated graft rejection.

Experiment II. Since the results of experiment I, in which pooled lymphoid tissue was used, were negative, CBA recipients were given in this experiment extracts prepared from $(a)$ spleen alone, $(b)$ pooled lymph-nodes, or $(c)$ the brachial and axillary lymph-nodes and those cervical lymph-nodes draining the skin graft. The lymphoid tissue was obtained from donors pre-sensitised to A-strain antigens, as in experiment $\mathrm{I}$. 
The results of this experiment are shown in table II. There was no evidence of accelerated graft rejection, no matter from which source the lymphoid cells were derived.

\section{TABLE I}

Survival of A-strain skin grafts on normal CBA mice treated with repeated intraperitoneal injections of lymphoid cell extract from pre-sensitised syngeneic donors

\begin{tabular}{|c|c|c|c|c|c|c|c|c|c|}
\hline \multirow{2}{*}{$\begin{array}{l}\text { Sensitisation of CBA } \\
\text { donors to A-strain } \\
\text { antigens }\end{array}$} & \multirow{2}{*}{$\begin{array}{l}\text { Fraction } \\
\text { transferred to } \\
\text { CBA recipients }\end{array}$} & \multirow{2}{*}{$\begin{array}{l}\text { Number } \\
\text { of grafts } \\
\text { inspected }\end{array}$} & \multicolumn{7}{|c|}{$\begin{array}{l}\text { Number of A-strain skin grafts } \\
\text { showing } 100 \text { per cent. epithelial } \\
\text { survival on day after grafting }\end{array}$} \\
\hline & & & 6 & 8 & 10 & 12 & 14 & 16 & 18 \\
\hline None & None & 30 & 30 & 30 & 22 & 16 & 3 & 0 & 0 \\
\hline None & Supernatant & 8 & 8 & 8 & 6 & 4 & 0 & 0 & 0 \\
\hline None & Sediment & 9 & 9 & 9 & 7 & 6 & 2 & 0 & 0 \\
\hline $\begin{array}{l}\text { Nuchal graft and } \\
25 \times 10^{6} \text { spleen cells }\end{array}$ & $\begin{array}{l}\text { Supernatant } \\
\text { Sediment }\end{array}$ & $\begin{array}{l}6 \\
8\end{array}$ & $\begin{array}{l}6 \\
8\end{array}$ & $\begin{array}{l}6 \\
6\end{array}$ & $\begin{array}{l}5 \\
6\end{array}$ & $\begin{array}{l}3 \\
3\end{array}$ & $\begin{array}{l}2 \\
1\end{array}$ & $\begin{array}{l}1 \\
0\end{array}$ & $\begin{array}{l}0 \\
0\end{array}$ \\
\hline
\end{tabular}

TABLE II

Survival of A-strain skin grafts on normal CBA mice treated with repeated intraperitoneal injections of extracts of lymphoid cells from various sites in pre-sensitised syngeneic donors

\begin{tabular}{|c|c|c|c|c|c|c|c|c|c|}
\hline \multirow[t]{2}{*}{$\begin{array}{l}\text { Sensitisation of CBA donors } \\
\text { to A-strain antigens }\end{array}$} & \multirow[t]{2}{*}{$\begin{array}{c}\text { Source of } \\
\text { lymphoid cells }\end{array}$} & \multirow[t]{2}{*}{$\begin{array}{c}\text { Fraction } \\
\text { transferred to } \\
\text { CBA recipients }\end{array}$} & \multirow[t]{2}{*}{$\begin{array}{l}\text { Number of } \\
\text { grafts } \\
\text { inspected }\end{array}$} & \multicolumn{6}{|c|}{$\begin{array}{c}\text { Number of A-strain } \\
\text { skin grafts showing } \\
100 \text { per cent. epithelial } \\
\text { survival on day after } \\
\text { grafting }\end{array}$} \\
\hline & & & & 6 & 8 & 10 & 12 & 14 & 16 \\
\hline None & ... & None & 30 & 30 & 30 & 22 & 16 & 3 & 0 \\
\hline $\begin{array}{l}\text { Nuchal graft and } \\
25 \times 10^{6} \text { spleen cells }\end{array}$ & $\begin{array}{l}\text { Spleen } \\
\text { Spleen }\end{array}$ & $\begin{array}{l}\text { Supernatant } \\
\text { Sediment }\end{array}$ & $\begin{array}{r}10 \\
9\end{array}$ & $\begin{array}{r}10 \\
9\end{array}$ & $\begin{array}{r}10 \\
9\end{array}$ & $\begin{array}{l}8 \\
6\end{array}$ & $\begin{array}{l}5 \\
4\end{array}$ & $\begin{array}{l}2 \\
2\end{array}$ & $\begin{array}{l}\mathbf{0} \\
\mathbf{0}\end{array}$ \\
\hline $\begin{array}{l}\text { Nuchal graft and } \\
25 \times 10^{6} \text { spleen cells }\end{array}$ & $\begin{array}{l}\text { Pooled } \\
\text { lymph-nodes }\end{array}$ & $\begin{array}{l}\text { Supernatant } \\
\text { Sediment }\end{array}$ & $\begin{array}{r}10 \\
8\end{array}$ & $\begin{array}{r}10 \\
8\end{array}$ & $\begin{array}{r}10 \\
8\end{array}$ & $\begin{array}{l}9 \\
7\end{array}$ & $\begin{array}{l}6 \\
5\end{array}$ & $\begin{array}{l}3 \\
2\end{array}$ & $\begin{array}{l}\mathbf{0} \\
\mathbf{0}\end{array}$ \\
\hline $\begin{array}{l}\text { Nuchal graft and } \\
25 \times 10^{6} \text { spleen cells }\end{array}$ & $\begin{array}{l}\text { Draining } \\
\text { lymph-nodes }\end{array}$ & $\begin{array}{l}\text { Supernatant } \\
\text { Sediment }\end{array}$ & $\begin{array}{l}6 \\
6\end{array}$ & $\begin{array}{l}6 \\
6\end{array}$ & $\begin{array}{l}6 \\
6\end{array}$ & $\begin{array}{l}5 \\
5\end{array}$ & $\begin{array}{l}4 \\
4\end{array}$ & $\begin{array}{l}3 \\
2\end{array}$ & $\begin{array}{l}0 \\
0\end{array}$ \\
\hline
\end{tabular}

Experiment III. Minor genetic differences between the A and CBA mouse strains used might be held responsible for the discrepancy between our findings and those of Najarian and Feldman (1963). As an attempt to cover this possibility, experiment III was carried out by the use of the strain combinations $\mathrm{A} \rightarrow \mathrm{CBA}, \mathrm{CBA} \rightarrow \mathrm{A}$ and $\mathrm{CBA} \rightarrow \mathrm{C} 3 \mathrm{H}$. The procedure was identical with that previously described, except that donors received bilateral grafts on the thorax 
instead of a triangular nuchal graft. Two sets of controls were set up for each strain combination. In one control group recipient mice were grafted with allogeneic skin only, but in the other, recipient mice grafted with allogeneic skin received injections of lymphoid cell extracts from unsensitised syngeneic donors.

The results of this experiment are shown in table III. It is clear that there was no indication of second-set rejection of any of the test grafts, irrespective of the mouse strain used as recipients or as the source of sensitising antigen.

Experiment $I V$. This experiment was carried out to demonstrate that intact, washed, sensitised lymphoid cells were capable of transferring homograft sensitivity when administered intraperitoneally to normal isogeneic recipients. To add more weight to this experiment, donors of lymphoid cells were sensitised with a single lateral skin graft only: this was a much less powerful stimulus than that given to donors in our three previous experiments, and in the experiments of Najarian and Feldman (1963). Also smaller numbers of cells were given compared with the mouse equivalent (ME) used in the other experiments.

Recipient CBA mice were given a single, laterally placed, A-strain skin graft. Twenty-four hours after grafting, these animals were given an intraperitoneal injection of either $50 \times 10^{6}$ lymph-node cells, or $100 \times 10^{6}$ spleen cells from CBA mice sensitised 10 days previously.

The test grafts were inspected when they had been in position 8 days-i.e., 7 days after cell transfer. Of the ten recipients given an injection of lymph-node cells, 7 showed advanced breakdown of the graft, 2 showed partial breakdown, and only 1 graft had an intact epithelium. In the group given spleen cells, 3 grafts showed advanced breakdown, 4 showed partial breakdown, and 3 had intact epithelium. All CBA animals that received an A-strain skin graft only (see table I) had intact epithelium at 8 days.

\section{Histological observations}

Microscopic examination of the grafts removed 6 days after transplantation in experiments I, II and III failed to show any signs of epidermal necrosis. This was true whether the graft was obtained from mice treated with extracts of pre-sensitised syngeneic lymphoid cells, from mice treated with normal cell extracts, or from untreated animals.

\section{Discussion}

Najarian and Feldman (1963) and Najarian (1966) have reported experiments in which allogeneic skin grafts were destroyed through the agency of soluble factors derived from pre-sensitised syngeneic lymphoid (pooled spleen and lymph-nodes) cells. The claim (Najarian and Feldman, 1962) that such sensitised cells placed in a millipore chamber at some distance from a solid allogeneic skin graft caused accelerated rejection of that graft received no support from similar experiments (Fujimoto et al., 1966; Wilson, Silvers and Billingham, 1966).

Furthermore, the claim that homograft sensitivity could be passively transferred by means of a soluble agent ("transplantation antibody ") present in the 


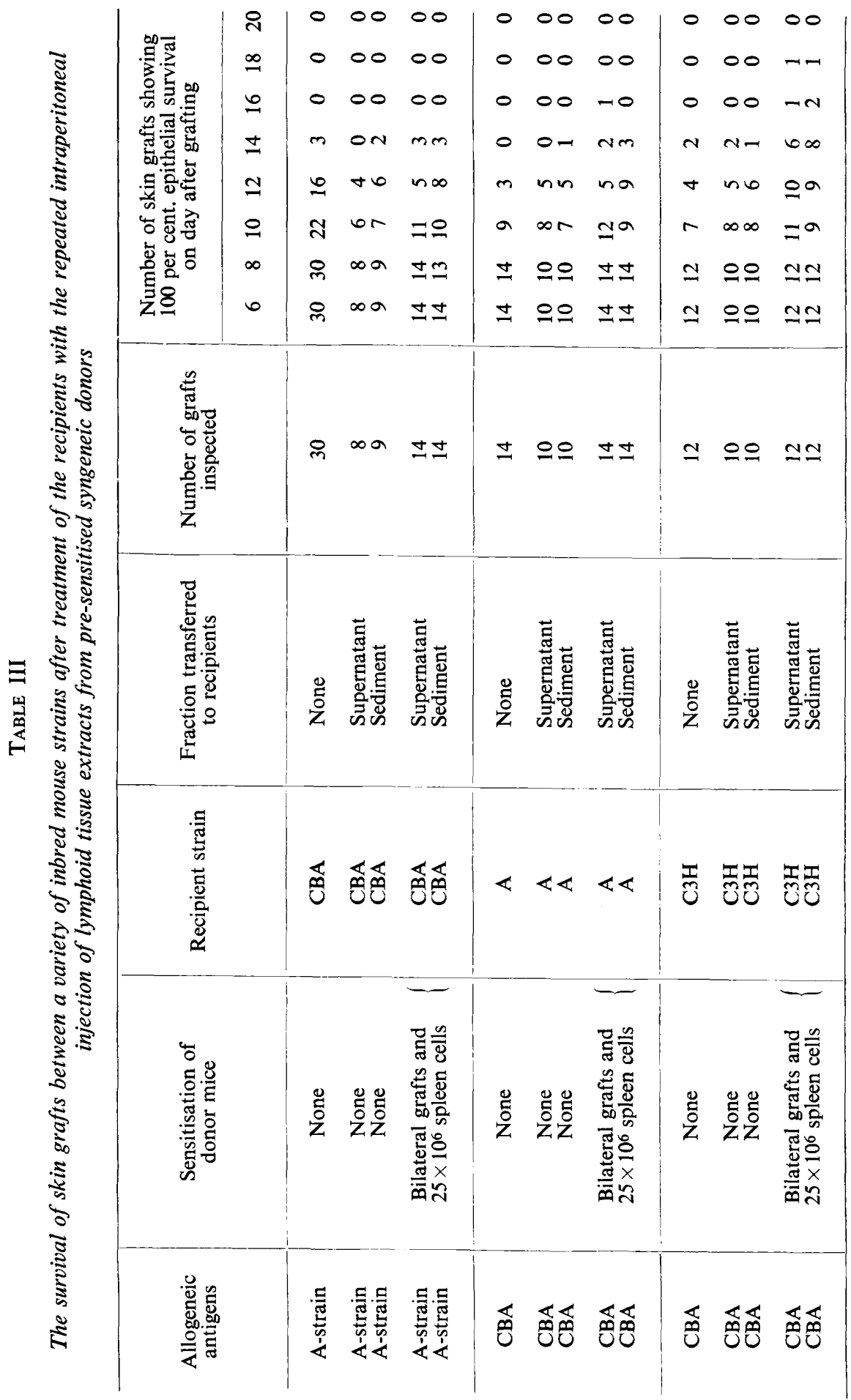


supernatant derived from sonicated lymphoid cells (pooled lymph-nodes and spleen) from sensitised syngeneic donors, is not supported by the experiments of Wilson (1965). He showed that the capacity of such supernatant fractions from sensitised cells to kill homologous target tumour cells in vitro was no greater than that of similar preparations from unsensitised animals.

In this investigation we have attempted to repeat directly the experiments of Najarian and Feldman (1963). The first of our experiments followed closely the techniques of these authors, but the results in table I show no evidence whatever of accelerated rejection of the test homografts by the supernatant fraction from sonicated pre-sensitised syngeneic lymphoid cells; this was confirmed by our microscopical findings.

We thought it possible that, in experiment $I$, when sensitised cells from various situations in the body were pooled, inactive material from one location might in some way mask the effective transfer of sensitivity by material obtained from another different location. The results of experiment II (table II), however, rule out this possibility. Extracts made separately from spleen, pooled lymph-nodes or draining lymph-nodes gave no indication of reducing the time taken for the rejection of grafts.

It is possible that our failure to repeat the positive results of Najarian and Feldman (1963) is due to minor genetic differences between their and our sublines of mice. It is clear from experiment III (table III) in which various strain combinations were used, that this is unlikely to be an untoward characteristic of the particular sublines available to us. The results from this experiment would seem to suggest that the repeated injection of fractions from sonicated pre-sensitised lymphoid cells tends to prolong rather than shorten the life of allogeneic skin grafts.

There is one difference between our experiments and those of Najarian and Feldman (1963). We have not favoured the lengthy periods of sonication used by these authors, although our times are comparable with those used by Wilson who also obtained negative results in his in-vitro system. As sonication produces intense local heating effects (and presumably heat denaturation), the shortest period that would guarantee disruption of the majority of cells seemed to be preferable. In using a short time of sonication $(2 \mathrm{~min}$.) and a larger estimate for the mouse equivalent $\left(250 \times 10^{6}\right.$ cells as opposed to the $150 \times 10^{6}$ of Najarian and Feldman, 1963) we should have provided ample opportunity for positive results due to antigen carry-over to be manifest. At no time, however, has there been any indication, either microscopic or macroscopic, of accelerated graft rejection.

Experiment IV amply demonstrates the ability of intact, viable pre-sensitised syngeneic lymphoid cells to transfer homograft sensitivity. One single intraperitoneal injection of such cells, at a much lower dose than that effectively used in the experiments involving the repeated injection of sonicated extracts, was sufficient to produce accelerated graft rejection.

On the basis of our experiments, therefore, we can find no evidence which would support the claim for a soluble "transplantation antibody" present in the supernatant fraction obtained from sonicated sensitised lymphoid cells. 


\section{SUMMARY}

The claim that passive transfer of homograft sensitivity could be achieved by the " injection of the supernatant obtained from tissue-sensitized lymphoid cells ... by sonic vibration" (Najarian and Feldman, 1963) has been investigated. We repeated the original experiments, but could not confirm the observation; furthermore, we could not transfer homograft sensitivity passively with extracts of sonicated sensitised lymphoid tissue from different sites (spleen or pooled lymph-nodes or draining lymph-nodes), or with extracts of lymphoid tissue of mice sensitised with grafts from several strains. In our hands, extracts of sonicated sensitised lymphoid tissue invariably failed to produce accelerated graft rejection.

\section{REFERENCES}

Billingham, R. E., ANd Brent, L. $\quad$. 1959. Phil. Trans. Roy. Soc. B, 242, 439.

Billingham, R. E., ANd Medawar, P. B. 1951. J. Exp. Biol., 28, 385.

Fujimoto, Y., Hasegawa, T., Watson, 1966. Transplantation, 4, 668.

C. G., AND BROOKS, J. R.

NAJARIAN, J. S.

1966. In The lymphocyte in immunology and haemopoiesis, ed. by J. M. Yoffey, London, p. 266.

Najarian, J. S., AND Feldman, J. D. $\quad$. 1962. J. Exp. Med., 115, 1083.

" " " $\quad$ " . 1963. Ibid., 118, 759.

WILSON, D. B. . " . . . . 1965. Ibid., 122, 143.

Wilson, D. B., Silvers, W. K., AND 1966. Nature, Lond., 209, 1359.

BILLINGHAM, R. E. 